\title{
THE RELATIONSHIP BETWEEN IRON STORAGE AND ANAEMIA
}

\author{
BY \\ W. M. DAVIDSON AND R. F. JENNISON \\ From the Department of Clinical Pathology, King's College Hospital, London
}

(RECEIVED FOR PUBLICATION OCTOBER 31, 1951)

In addition to the iron of the haemoglobin and other pigments in active use in the body, there is a quantity stored as ferritin and haemosiderin in the parenchymal and reticulo-endothelial cells. The iron protein complex, ferritin, is difficult to demonstrate as it occurs as a diffuse non-particulate material, but haemosiderin can readily be seen as it forms golden granules which give an iron reaction with the ordinary histochemical methods.

It has been suggested that of these two compounds ferritin is the more labile and readily takes part in the synthesis of haemoglobin, whereas haemosiderin is the reserve store formed, either as the result of denaturation of haemoglobin or by polymerization when there is adequate ferritin already present (Granick, 1949). Thus the readily demonstrable haemosiderin should reflect the amount of ferritin hidden in the cells. Any estimate of these stores of iron would obviously be important in elucidating the cause of many anaemias, and with this in view an attempt has been made to find the relationship between the quantity of readily demonstrable iron in the bone marrow and the various types of anaemia. As the marrow aspirates are sectioned as a routine in this laboratory, the addition of a Prussian blue stain for iron has not entailed much extra labour and such preparations have been used throughout the present work. So far 181 satisfactory specimens from 165 patients have been analysed, 72 with simultaneous serum iron estimations.

Rath and Finch (1948) studied the iron content of the sternal marrow in cover-slip preparations stained by a Berlin blue method, and since the publication of their work we have also tried this method, but in our hands the results have not been nearly as precise as those obtained from sections. When there are large numbers of iron-containing cells they are readily found in squash preparations and even in smears, but the difficulty arises in the negative or near-negative cases. Even with traces of iron, marrow sections give clearly positive results because of the undisturbed cell arrangement.
In contradiction to the findings of Masshoff and Gruner (1951) we have found that the marrow iron and the type of anaemia are related in as far as iron metabolism is involved. On their findings, three quarters of the cases they investigated would fall into our miscellaneous group in which there is no such direct relationship.

\section{Material and Methods}

Marrow was aspirated from the iliac crest, sternum, or vertebral spines of the tibia using a Salah needle. The material was put into a watch glass and without loss of time particles of marrow were transferred to slides with a pipette and smear and squash preparations made. The remainder was allowed to coagulate, then freed at the edge to allow adequate contraction of the clot and after about half an hour transferred to FormolZenker fixative. The clot was fixed within 12 hours, and after removing the mercuric chloride it was dehydrated, embedded in paraffin, and sectioned.

Smears were stained by Jenner-Giemsa or MayGrunwald-Giemsa techniques and sections by haematoxylin and eosin, Prussian blue, and other methods as indicated. In the Prussian blue method used, equal quantities of $2 \%$ potassium ferrocyanide and $2 \% \mathrm{HCl}$ were mixed and brought almost to boiling point before being applied to the section. The stain was allowed to act for three minutes, and, after washing, the preparation was counterstained with $1 \%$ aqueous eosin.

The amount of iron present in the sections was graded as follows: (0) absolutely no intracellular iron demonstrable in adequate sections (at least two particles of cellular marrow sectioned, each not less than $1 / 3 \mathrm{~mm}$. in diameter, i.e., more than filling the $1 / 6 \mathrm{in}$. field of the microscope); (1) only an occasional cell containing iron; (2) 4-6 iron-containing cells per $1 / 6$ in. field; (3) 7-10 iron-containing cells per $1 / 6$ in. field; (4) many cells distended with iron pigment; (5) cells aggregating into iron-containing patches; (6) patches so large that they dominate the field. All marrows do not fall into these clear-cut categories, but to avoid unnecessary subdivision we have generally allotted the marrow to the higher grade. The normal grade is about 2. Grade 6 probably occurs only in heavily transfused patients. Figs. 1-4 illustrate the main grades. 


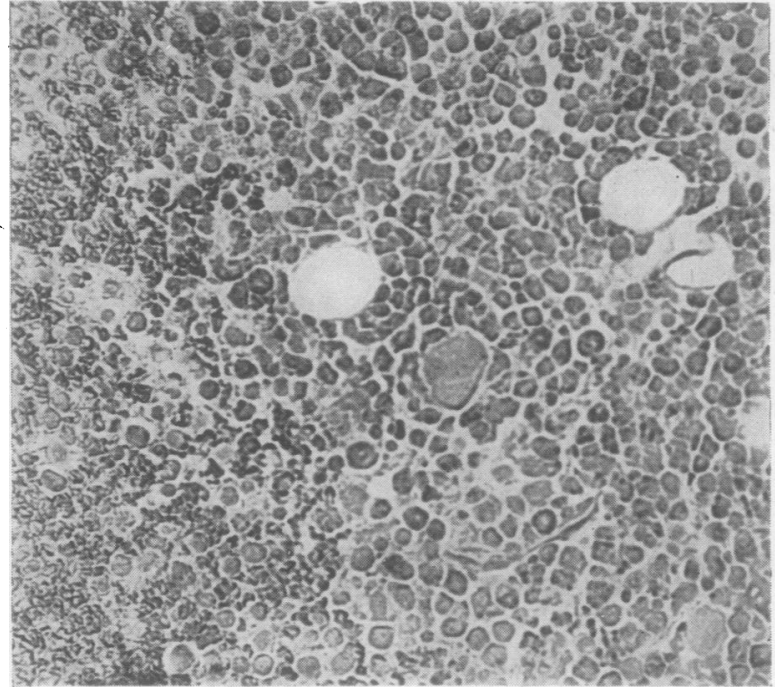

FIG. 1.-Grade 0: hypochromic anaemia; marked hyperplasia.

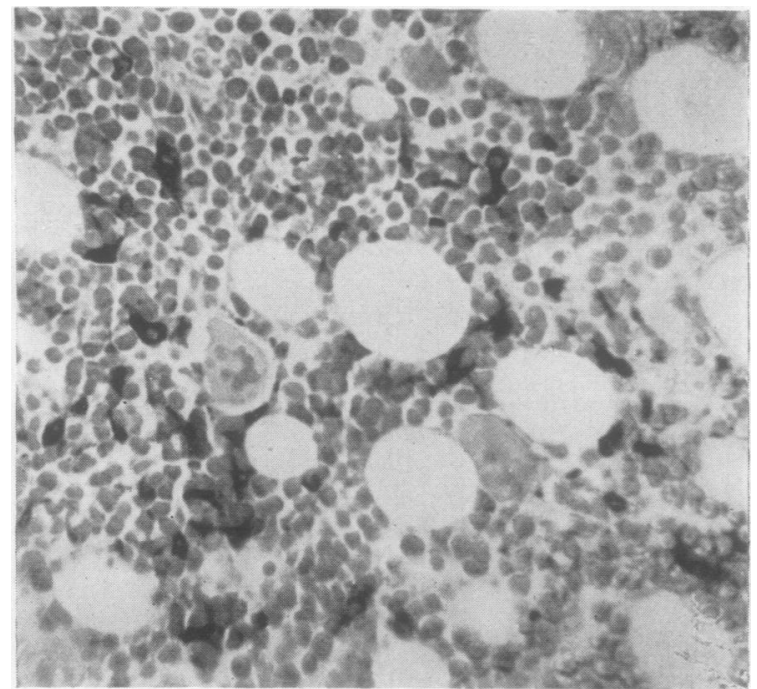

FIG. 3.-Grade 3: chronic infection; slight hyperplasia.
The serum iron was estimated by a method similar to that used by Dahl (1948). Employing iron-free glassware throughout, $5 \mathrm{ml}$. of serum was incubated at $37^{\circ} \mathrm{C}$. for one hour with $2.5 \mathrm{ml}$. of $5 \% \mathrm{HCl}$ to free the iron from its protein complex. Then $5 \mathrm{ml}$. of $20 \%$ trichloracetic acid was added and allowed to act for two hours. The tubes were centrifuged to deposit the precipitated proteins and $5 \mathrm{ml}$. of the supernatant transferred to another tube. Concentrated $\mathrm{HNO}_{3}$, $0.14 \mathrm{ml}$., was added followed by $1.4 \mathrm{ml}$. of $5 \mathrm{~N}$ KCNS and the colour read at once in a photo-electric absorptiometer using an Ilford spectral filter "604." The normal finding by this method is $130 \pm 30 \mu \mathrm{g}$. per $100 \mathrm{ml}$.

The normal marrows studied were obtained from patients who proved to have no disorder of the blood or blood-forming organs.

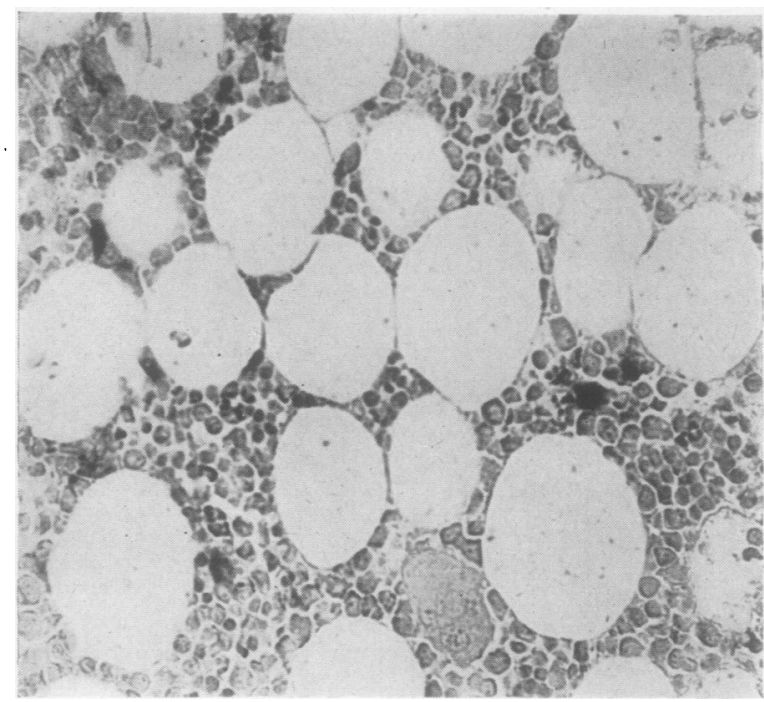

Fig. 2.-Grade 2: normal.

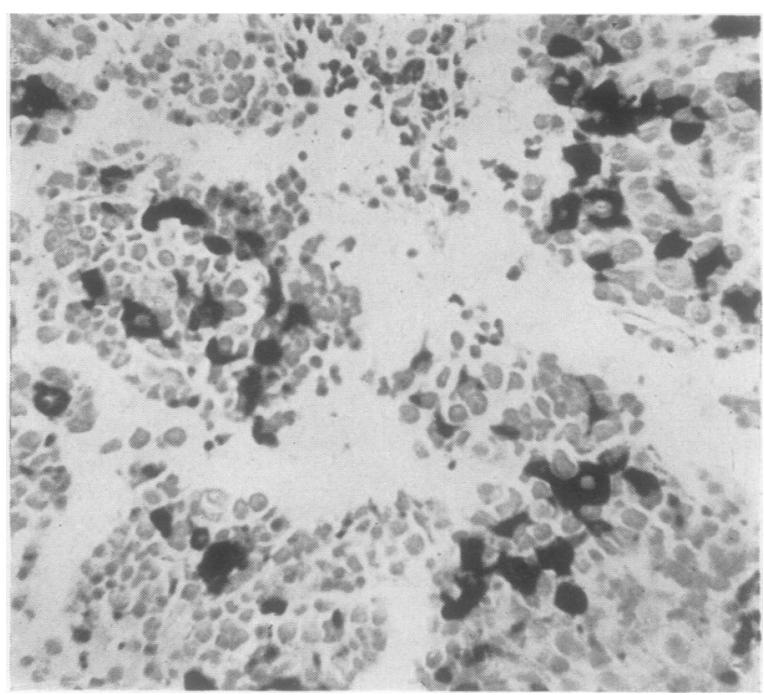

FIG. 4.-Grade 5: haemolytic anaemia; mult ple transfusions. $\times$ 260) stained Prussian blue.

\section{Results}

Table I shows the findings in all the marrows examined. It will be seen that the cases tend to fall into four groups. First, the megaloblastic anaemias which are independent of iron metabolism: if iron absorption is normal and there is no blood loss, iron tends to accumulate as a result of diminished erythropoiesis. Usually the serum iron reflects this accumulation and indicates a high percentage saturation of the total iron-combining capacity of the - serum.

The second group includes cases of chronic blood loss or failure to absorb iron. These in different ways result in a depletion of the marrow iron stores and a lowering of the serum iron level. 
Thirdly are those cases with anaemia due to a toxic cause such as a chronic sepsis or uraemia. Here iron is not used because of depressed erythropoiesis, often associated with a disturbance of

TABLE I

SURVey of all Marrows Examined

\begin{tabular}{|c|c|c|c|c|c|c|c|c|}
\hline & \multirow{2}{*}{ No. } & \multicolumn{7}{|c|}{ Grade } \\
\hline & & 0 & 1 & 2 & 3 & 4 & 5 & 6 \\
\hline $\begin{array}{l}\text { Apparently normal } \\
\text { Haemochromatosis }\end{array}$ & 11 & - & 4 & 5 & 2 & - & - & - \\
\hline $\begin{array}{l}\text { Haemochromatosis } \\
\text { Pernicious anaemia and/or } \\
\text { subacute combined degen- } \\
\text { eration: }\end{array}$ & 1 & - & - & - & 一 & 1 & - & 一 \\
\hline $\begin{array}{ccc}\text { Untreated } & . . & . .\end{array}$ & 33 & 3 & 7 & 6 & 8 & 9 & 一 & - \\
\hline Other megaloblastic anae- & & & & & & - & - & - \\
\hline$\underset{\text { Iron deficiency anaemia: }}{\operatorname{mias}}$ & 8 & - & 3 & - & 1 & 4 & 一 & - \\
\hline $\begin{array}{ll}\text { Untreated } & \ldots \\
\text { Treated orally } & \ldots\end{array}$ & 32 & 30 & 2 & - & 一 & 一 & 一 & - \\
\hline Treated intravenously & 3 & 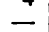 & $\sqrt{2}$ & 1 & 二 & 二 & 二 & $\bar{Z}$ \\
\hline Polycythaemia vera (chronic) & 4 & 3 & 1 & - & - & - & - & - \\
\hline $\begin{array}{l}\text { Steatorrhoea } \\
\text { Refractory }\end{array}$ & 3 & 3 & - & - & - & - & 一 & - \\
\hline $\begin{array}{lll}\text { anaemia } & \ldots & \ldots\end{array}$ & 3 & 一 & - & 2 & 1 & - & 一 & - \\
\hline $\begin{array}{l}\text { Pellagra } \\
\text { Chronic infection .. }\end{array}$ & $\begin{array}{r}1 \\
10\end{array}$ & 二 & $\overline{1}$ & 二 & $\begin{array}{l}1 \\
2\end{array}$ & $\overline{5}$ & $\overline{2}$ & 二 \\
\hline Bacterial endocarditis & 2 & - & 1 & 1 & - & - & - & - \\
\hline Uraemia & 5 & - & 1 & 2 & 1 & 1 & - & - \\
\hline $\begin{array}{l}\text { Malignant disease } \\
\text { Reticuloses }\end{array}$ & $\begin{array}{l}5 \\
5\end{array}$ & $\begin{array}{l}1 \\
2\end{array}$ & 1 & 1 & 1 & 1 & - & $\overline{1}$ \\
\hline Cirrhosis of liver .. & 1 & - & $i$ & - & - & - & - & - \\
\hline Multiple myeloma.: & 3 & 1 & - & 1 & 1 & 二 & 二 & 二 \\
\hline Hyperglobulinaemia & 21 & 2 & $\overline{7}$ & $\begin{array}{l}1 \\
5\end{array}$ & $\overline{4}$ & $\overline{1}$ & $\overline{2}$ & 二 \\
\hline Neutropenia $\quad \because$. & 2 & - & 1 & 1 & 二 & - & - & 二 \\
\hline Haemolytic anaemia: & & & & & & & & \\
\hline $\begin{array}{ll}\text { Acquired } & \cdots \\
\text { Congenital } & \cdots\end{array}$ & 2 & $\overline{1}$ & 二 & $\overline{1}$ & 1 & - & 1 & 二 \\
\hline Nocturnal haemoglobinuria & 1 & 1 & $\bar{z}$ & 1 & 二 & 二 & 二 & 二 \\
\hline Erythroblastosis ... . . & 2 & $i$ & 1 & - & - & - & - & - \\
\hline Thrombocytopenia & 1 & - & 1 & - & - & $\rightarrow$ & - & - \\
\hline Congenital porphyria & 2 & 1 & - & - & - & 1 & $\overline{1}$ & - \\
\hline $\begin{array}{l}\text { Porphyrinuria (? alcoholic) } \\
\text { Still's disease }\end{array}$ & 1 & 二 & 二 & $\overline{1}$ & 二 & 二 & 1 & 二 \\
\hline Gaucher's disease ... & 1 & - & - & 1 & - & - & - & 二 \\
\hline Splenomegaly $\quad .$. & 1 & 1 & - & - & - & - & - & 一 \\
\hline Total & 181 & & & & & & & \\
\hline
\end{tabular}

protein metabolism, or is not available for haemoglobin formation through an increased affinity of the tissues for iron, as has been suggested by Greenberg, Ashenbrucke:, Lauritsen, Worth, Humphreys, and Wintrobe (1947). Despite the presence of stored iron these cases tend to have a low serum iron content.

Finally comes the group of miscellaneous conditions which show no characteristic relationship. In most of these any changes in the iron content can be correlated with the presence of other factors bringing them into line with the second and third groups.

\section{Discussion}

The Megaloblastic Anaemias.-In general iron is present in this group. The five exceptions were investigated before serum iron estimations were made, but the patients' histories suggest an associated iron deficiency. One was from a woman of

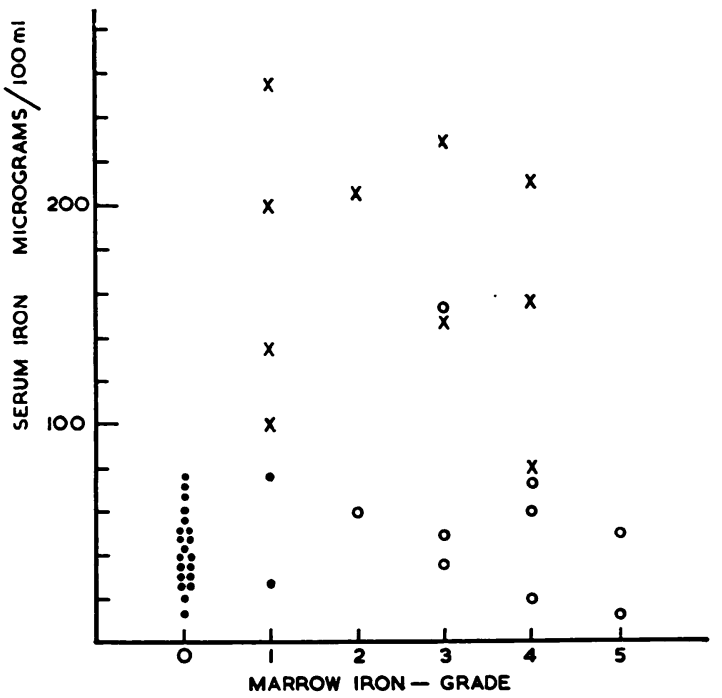

FIG 5.-Diagram showing relationship between serum iron and marrow iron. untreated hypochromic anaemias, idiopathic or due to chronic haemorrhage $\times$ untreated pernicious anaemia. $O$ chronic infection and uraemia of more than three weeks duration.

40 who in addition to pernicious anaemia had had severe menorrhagia for some years. The pernicious anaemia responded adequately to vitamin $B_{12}$, but a satisfactory haemoglobin level was only maintained after hysterectomy. Another patient had lived on a "bread and tea" diet for many years. The third and fourth marrows (in the treated and untreated lines) were from the same woman who had subacute combined degeneration with a megaloblastic marrow and a M.C.H.C. of $29 \%$. This patient required iron therapy as well as vitamin $B_{12}$. The fifth specimen was from a man with subacute combined degeneration. It was taken after treatment; the initial level had been grade 2 . Apart from the case which remained at grade 0 , and G.Fi. (Table II) in whom the amount of iron present on both occasions was very small indeed, all patients from whom satisfactory marrows were obtained before and after treatment showed a drop in iron content. Examples are:

Mrs. $H$.-In 10 weeks there was a fall from grade 4 to grade 1 while the haemoglobin rose from $6.9 \mathrm{~g}$. to $11.4 \mathrm{~g}$. per $100 \mathrm{ml}$.

Mrs. D.-In two weeks iron content dropped from grade 3 to 1 with a rise from $7.1 \mathrm{~g}$. to $11.7 \mathrm{~g}$. per $100 \mathrm{ml}$.

It is interesting that among the untreated patients five of the seven specimens in grade 1 came from women of menopausal age who had been treated with oral iron before pernicious anaemia was diagnosed. Four of these, E.A., G.Fi., M.F., and $W . Y$., also appear in Table II. The three specimens under "other megaloblastic anaemias" in grade 1 were all from a patient with recurrent pernicious anaemia of pregnancy occurring in the puerperium, and it is possible that the pregnancy depleted the iron store in spite of oral iron therapy. 
TABLE II

Megaloblastic Anaemias

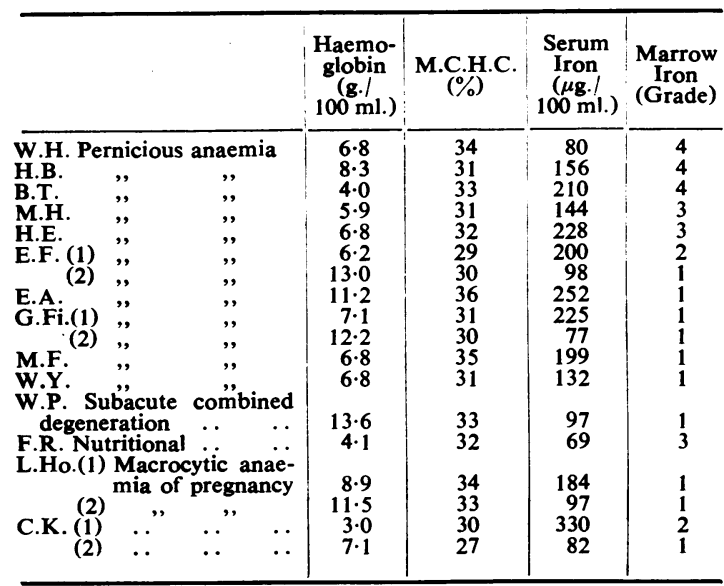

The Hypochromic Anaemias.-It is probable that ordinary hypochromic anaemia only develops after the exhaustion of the iron store, although as some of the haemosiderin iron is difficult to mobilize, traces might be found in early cases, but we have not seen this stage. The two patients with simple hypochromic anaemia with a small amount of iron in the marrow (Table III) were relapsing after intravenous therapy. C.S. had been given $0.975 \mathrm{~g}$. of "ferrivenin" six months previously which brought his haemoglobin to $13.5 \mathrm{~g}$./100 ml., but he had relapsed. A further complication was that he had received deep $x$-ray therapy for ankylosing spondylitis. G.P. had had a transfusion of 2 pints of blood three months previously.

The two cases with the highest serum iron values (82 and $95 \mu \mathrm{g} . / 100 \mathrm{ml}$.), M.Lu. and P.G. (Table III), had already started oral iron when the specimens were taken.

It is interesting that none of the four patients treated with oral iron had developed iron deposits (Table I). One, a man with chronic haemorrhage, had been treated with oral iron for six months during which time his haemoglobin rose from $5.1 \mathrm{~g}$. to $14.8 \mathrm{~g}$. The other three cases also appear in both tables. J.A. was treated for 10 months and the haemoglobin rose from $6.0 \mathrm{~g}$. to $17.4 \mathrm{~g}$. $/ 100 \mathrm{ml}$.; $E . K$. for four months with a rise from $9.4 \mathrm{~g}$. to $13.2 \mathrm{~g}$. $/ 100 \mathrm{ml}$; ; and M.G. for several months without response. The low serum iron in the last patient suggested a failure of absorption and this was confirmed by the response to intravenous iron therapy. The two specimens graded 1 after treatment (Table I) were from a man whose haemoglobin level had risen from $6.0 \mathrm{~g}$. to $10.5 \mathrm{~g}$. $/ 100 \mathrm{ml}$. after blood transfusi $n$ and "ferrivenin" therapy.
The marrow in grade 2 was from a patient who had $1.2 \mathrm{~g}$. "ferrivenin" with a rise in haemoglobin level from $8.7 \mathrm{~g}$. to $15.7 \mathrm{~g} . / 100 \mathrm{ml}$. Although the number of treated cases shown here is still small, the results agree with the experimental findings of other

TABLE III

HYPOCHROMIC ANAEMIAS*

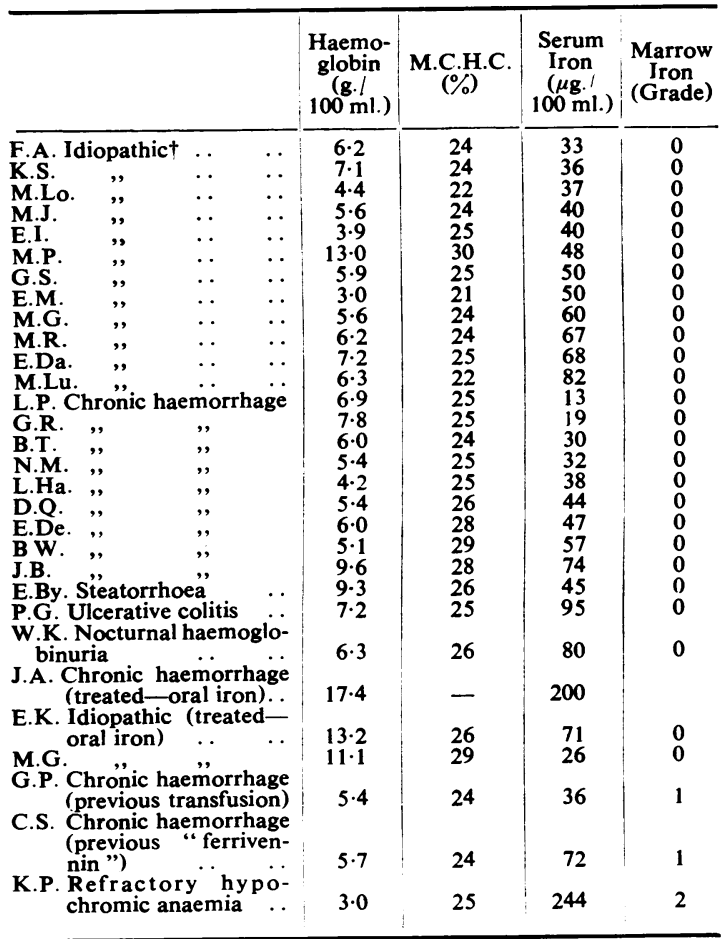

* Microcytic or normocytic with M.C.H.C. below $30 \%$.

+ Term applied to all cases in which there was no demonstrable blood loss, despite the fact that in a few instances no attempt was made to demonstrate the achlorhydria.

workers that oral iron corrects the anaemia in iron deficiency states if absorption is normal or increased as it often is in these cases (Copp and Greenberg, 1946), but once the anaemia is corrected iron absorption ceases and the stores remain depleted (Fontès and Thivolle, 1936). Finch, Hegsted, Kinney, Thomas, Rath, Haskins, Finch, and Fluharty (1950) working with animals have shown that oral iron tends to increase the iron content of the liver first and the reticuloendothelial system later, whereas intravenous iron seems to accumulate to a greater extent in the R.E.S.

Two patients in Table III require explanation. $W . K$., who had had nocturnal haemoglobinuria for seven years, had such large losses of haemoglobin in the urine during the attacks that he had used up his iron store. K.P., a baby girl, presented at 6 weeks 
with a severe anaemia (haemoglobin $3.0 \mathrm{~g} . \%$ ) which showed all the features of iron deficiency. Treatment with oral iron had no effect, as was to be expected, because the serum iron estimations and the iron content of the hyperplastic bone marrow showed that there was no shortage of iron. The child has been kept alive by transfusions and has developed normally, apart from bone changes due to marrow hyperplasia.

Anaemias Due to "Toxic" Causes.-In these (Table IV) the iron stores are normal or increased except in two patients with associated chronic haemorrhage, and one early case of bacterial endocarditis with very little anaemia. In all but one (G.C., suffering from uraemia) the serum iron is well below normal levels, indicating the increased tendency to transfer iron from the serum to the tissues.

TABLE IV

Toxic anaemias Caujed by Chronic Infection or Uraemia*

\begin{tabular}{|c|c|c|c|c|}
\hline & $\begin{array}{c}\text { Haemo- } \\
\text { globin } \\
(\mathrm{g} . / \\
100 \mathrm{ml} .)\end{array}$ & $\underset{(\%)}{\text { M.C.H.C. }}$ & $\begin{array}{c}\text { Serum } \\
\text { Jron } \\
(\mu \mathrm{g} \cdot / \\
100 \mathrm{ml} .)\end{array}$ & $\begin{array}{l}\text { Marrow } \\
\text { lron } \\
\text { (Grade) }\end{array}$ \\
\hline 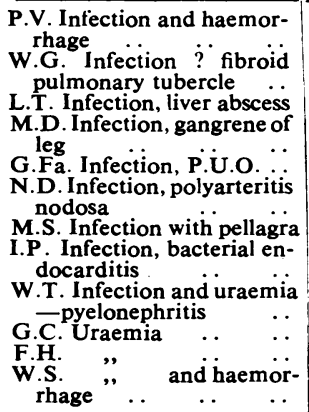 & $\begin{array}{r}11.4 \\
9.9 \\
8.4 \\
6.0 \\
10.5 \\
7.5 \\
7.5 \\
13.8\end{array}$ & $\begin{array}{l}32 \\
32 \\
36\end{array}$ & $\begin{array}{r}13 \\
154 \\
59\end{array}$ & $\begin{array}{l}5 \\
3 \\
2\end{array}$ \\
\hline
\end{tabular}

* Anaemia in cases with chronic infections of usually more than three weeks' duration and chronic uraemia (blood urea higher than $100 \mathrm{mg} . \%$ )

Miscellaneous Group.-In the miscellaneous group the leukaemias show wide variations, in part due to the fact that the iron-containing cells are sometimes difficult to see because of the infiltration. One of these patients G.R. (grade 5) had severe haemolytic anaemia of some weeks' duration, while at the other extreme G.B. (grade 0 ) had recently been pregnant. Similarly, in the reticuloses group the iron is obscured, but one patient with haemolytic anaemia treated by multiple transfusions reached grade 6 . One patient with congenital porphyria (M.P., Table III) had mild hypochromic anaemia of dietetic origin and no iron in the marrow, whereas the other (G.L., Table V) had haemolytic anaemia and grade 4 iron. G.R., the patient with acquired haemolytic anaemia with grade 5 iron, had had many blood transfusions before the marrow examination was carried out.
TABLE V

Miscellaneous

\begin{tabular}{|c|c|c|c|c|}
\hline & $\begin{array}{c}\text { Haemo- } \\
\text { globin } \\
\text { (g./ } \\
100 \mathrm{ml} .)\end{array}$ & $\underset{(\%)}{\text { M.C.H.C. }}$ & $\begin{array}{c}\text { Serum } \\
\text { Iron } \\
(\mu \mathrm{g} . / \\
100 \mathrm{ml} .)\end{array}$ & $\begin{array}{l}\text { Marrow } \\
\text { Iron } \\
\text { (Grade) }\end{array}$ \\
\hline 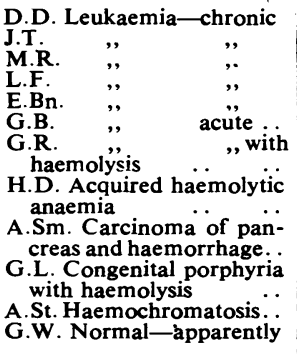 & $\begin{array}{r}12 \cdot 0 \\
4 \cdot 5 \\
14 \cdot 1 \\
13 \cdot 5 \\
9.0 \\
7 \cdot 1 \\
3 \cdot 0\end{array}$ & $\begin{array}{l}31 \\
32 \\
33 \\
32 \\
31 \\
36 \\
35 \\
36\end{array}$ & $\begin{array}{r}86 \\
100 \\
113 \\
85 \\
162 \\
112\end{array}$ & $\begin{array}{l}2 \\
3 \\
1 \\
1 \\
1 \\
0 \\
5\end{array}$ \\
\hline
\end{tabular}

\section{Summary}

The amount of haemosiderin visible in sections of the bone marrow, the serum iron level, and the type of anaemia have been correlated in a series of consecutive haematological cases.

On this basis the patients have been divided into four groups, three with definite characteristics. In iron deficiency anaemia there is no store of iron in the marrow, even after successful oral iron therapy, and the serum iron is low: in pernicious anaemia the marrow and serum iron levels are raised but fall during treatment: in the anaemia of sepsis and uraemia the marrow iron is high but the serum iron is low; in the miscellaneous fourth group the marrow iron level depends in the main on whether there has been concomitant blood loss, sepsis, or haemolysis, while the highest levels are found in patients treated by repeated blood transfusions. Certain apparent variations have been explained.

The findings suggest that the routine use of the combined marrow and serum iron estimations provides a valuable weapon in investigating cases of anaemia and even in assessing the prognosis in some instances. It is of particular use in determining the part played by chronic sepsis in anaemia, and in localizing a failure in iron metabolism to intake, absorption, excessive loss, or defective utilization.

We wish to thank Mr. G. A. Harwood for the histological preparations.

\section{REFERENCES}

Copp, D. H., and Greenberg. D. M. (1946). J. biol. Chem., 164, 377. Dahl, S. (1948). Brit. med. J., 1, 731 .

Finch, C. A., Hegsted, M., Kinney, T. D., Thomas, E. D., Rath, C. E., Haskins, D., Finch, S., and Fluharty, R. G. (1950) Blood, 5, 983.

Fontès, G., and Thivolle, L. (1936). Sang, 10, 144.

Granick, S. (1949). Bull. N.Y. Acad. Med., 25, 403.

Greenberg, G. R., Ashenbrucker, A. Lauritsen, M. Worth, W. Humphreys, S. R., and Wintrobe, M. M. (1947). J. clin. Invest., 26, 121 .

Masshoff, W., and Gruner, P. (1951). Acta haemat., Basel, 5, 19. Rath, C. E., and Finch, C. A. (1948). J. Lab. clin. Med., 33, 81. 